\title{
Governance in Land Acquisition and Compensation for Infrastructure Development
}

\author{
Subash Ghimire ${ }^{1,}$, Arbind Tuladhar ${ }^{1}$, Sagar Raj Sharma ${ }^{2}$ \\ ${ }^{1}$ Department of Civil and Geomatics Engineering, School of Engineering, Kathmandu University, Dhulikhel, Nepal \\ ${ }^{2}$ Department of Development Studies, School of Arts, Kathmandu University, Lalitpur, Nepal
}

Email address:

subash_ghimire@ku.edu.np (S. Ghimire)

${ }^{*}$ Corresponding author

\section{To cite this article:}

Subash Ghimire, Arbind Tuladhar, Sagar Raj Sharma. Governance in Land Acquisition and Compensation for Infrastructure Development. American Journal of Civil Engineering. Vol. 5, No. 3, 2017, pp. 169-178. doi: 10.11648/j.ajce.20170503.17

Received: March 15, 2017; Accepted: March 31, 2017; Published: April 17, 2017

\begin{abstract}
Investment in infrastructure development such as road, railways, airport, hydropower, irrigation and town development for public purpose is very important for the development of any country and needs a huge quantity of land. The main objective of the paper is to find out the gaps on land acquisition and compensation processes for infrastructure development projects in Nepal. This research paper is based on the desk study using the experiences of the cases in infrastructure development projects in China, India, Malaysia and Norway. In this study, we emphasize three main issues for identifying the gaps in land acquisition and compensation and these are i) law and regulations, ii) procedure for land acquisition and compensation, and iii) land valuation approaches for compensation. The relevant land governance elements such as public participation, access to information, fair compensation, transparent procedure and stakeholder co-ordination are derived using the World Bank Land Governance Assessment Framework (LGAF) and UN-FAO Voluntary Guideline of Governance of Tenure. The study shows that the practices and processes in compulsory purchase and compensation are quite different in different countries due to its legal, social and political contexts. The study reveals that the different countries have different law and regulations, procedure for land acquisition and land valuation approaches depending upon social, political and economic conditions of the country. The major gap identified from the study about the situation in Nepal is the implementation aspects of land acquisition, compensation and land valuation system in reference to good governance principles namely public participation, access to information, transparent procedure and stakeholder's interaction.
\end{abstract}

Keywords: Governance, Acquisition, Compensation, Valuation, Infrastructure

\section{Introduction}

Land has always played a crucial role in life of human community and is basics to human existence and also a limited resource. It plays an important role as a financial asset. Investment in infrastructure development such as airport, road, railways, hydropower, irrigation and town development for public purpose is very important for the development of any country and any infrastructure development needs a huge quantity of land. The first step towards the public infrastructure development is the acquisition of land. Land acquisition is a process of acquiring private/public land and providing for the public benefits [1]. There are various ways to acquire land for infrastructure development [2]. The Voluntary purchase, land consolidation (readjusting) and compulsory purchase are the common ways for land acquisition in infrastructure development. The exchange of land is known as voluntary purchase. The land readjustment allows land assembly, especially when the budgets for compulsory purchase and infrastructure provision are limited. The land readjustment enhances development by re-parceling of land for better planning and distributing the benefits of the development. The compulsory purchase or expropriation is the method for acquiring the land. Expropriating land with low market value is common for the land acquisition in developing countries [3]. The issues such as land valuation, compensation, and violation of rights, loss of ownership and livelihood of affected people come together during land acquisition. Often infrastructure developmental 
activities dislocate families from their home, business from their neighbourhoods and farmers from their farms.. Therefore the proper valuation of land and compensation for lost asset are very important to reduce land conflicts with affected persons [4].

Land valuation is one of the main components of Land Administration, and its importance in infrastructure development is to develop sustainable infrastructure. The sustainable infrastructure is technically feasible, socially acceptable, economically viable and environment friendly. The sustainable infrastructure development project creates economic development that enhances the poverty reduction in the country. Therefore, efficient and effective land administration is very essential for sustainable development [5]. Land administration with proper parcel-based geoinformation system is very necessary for the people and government to ensure good tenure security for effective and efficient land transactions [6] and Land Administration supports in land valuation for land acquisition by providing the proper information of land ownership, land value and land use. The next paragraph mentions the examples of unsustainable infrastructure development in various countries.

In Srilanka, Upper Kotmale Hydropower Project was delayed because of lack of public participation during the project planning stage [7]. In many developing countries, top down approach is followed for policy formulation to acquire the land and public participation is not sufficiently available in the process of land acquisition and land valuation. Similarly the Yadana Natural Gas Pipeline Project in Thailand faced from the effects of public demonstration because project sponsors did not address the concerns of the public properly in its process [8]. Similarly, the project affected people suffered largely in Jamuna Bridge Project in Bangladesh due to low pricing of their land, the methods of providing compensation and government mechanisms related to land acquisition. Most of the respondents responded that they not only paid $10 \%$ to $15 \%$ of the money they received as bribes to the authorities in different government offices to receive their compensation, but that they faced many obstacles in every step of the process in collecting their compensation in cash. Many respondents responded that they received half compensation because they were helpless against those obstacles and finally decided not to go to the office to collect their compensation. It is also found that the land price had increased high just after the start of the land acquisition process, and that it was impossible for them to buy comparable land at a similar price [9].

Land governance is about determining and implementing sustainable land policies and establishing strong relationship between people and land [10]. In this context, land governance - refered to as policies, rules, processes- plays significant role on land acquisition and compensation. According to UNDP, good governance principles are participation, consensus orientation, strategic vision, responsiveness, effectiveness and efficiency, accountability, transparency, equity, rule of law [11]. Similarly, Land
Governance Assessment Framework (LGAF) developed by World Bank have distinguished the principles of good governance as integrity and accountability, efficiency and effectiveness, civic engagement \& public participation, equity, fairness \& impartiality, legal security and rule of law, subsidiary, autonomy, transparency, consistency \& predictability. According to Voluntary Guideline of Governance of Tenure (VGGT), the principles of good governance include: human dignity, non-discrimination, equity and justice, gender equality, holistic and sustainable approaches, consultation and participation, rule of law, transparency, accountability, and continuous improvement [12]. The principles of good governance such as transparency, public participation, accountability, access to information will determine the relationships between the stakeholders [13].

The main objective of the paper is to find out the gaps on i) law and regulations, ii) procedure for land acquisition and compensation, and iii) land valuation approaches for compensation. This will be done by analysing land governance principles such as public participation, access to information, transparent procedure and stakeholder's interaction in land acquisition and compensation. Transparency in information dissemination, decision making, involvement of key stakeholders on key issues and time bound solution can hardly be found during hydropower development [14]. An Acquisition compensation and rehabilitation plan (ACRP) is prepared as a project document following the process established in the Land Acquisition Act of Nepal. But institutional conditions like differentiating of affected people, low and unfair compensation, exclusion of directly affected families in compensatory procedures and lack of strong consultation processes enhances additional gaps that results instability amongst those affected by the dam intervention. Unless compensatory procedures are nicely laid out and implementation of plans is made transparent, hydropower projects are not sustainable in a developing country like Nepal with its limited land resources and intricacies of power within social relations [15].

Therefore, the land governance principles such as public participation, access to information, transparent procedure and stakeholder's interaction are crucial for delaying the infrastructure development projects. Therefore, these crucial elements are chosen for the study.

\section{Research Approach and Material}

For this research paper, we have adopted a case study approach to find out the gaps in land acquisition and compensation processes using the cases in China, India, Malaysia and Norway. As shown in figure 1, there are four steps in this research. The first step is about reviewing land governance elements that are relevant for land acquisition and compensation using the World Bank LGAF and UNFAO VGGT. Both these documents provide guidelines on land acquisition and compensation. Secondly, scientific literature review is conducted in infrastructure development 
to determine the major land issues in land acquisition and compensation. Secondary sources are used to collect the data of the cases. Good practices in land valuation, acquisition and compensation are reviewed from land Governance perspective from infrastructure development of Norway.
Norway is known for its particular expertise in the development of efficient, environment-friendly infrastructure development. Finally, based on the first and second steps, major land governance elements are identified.

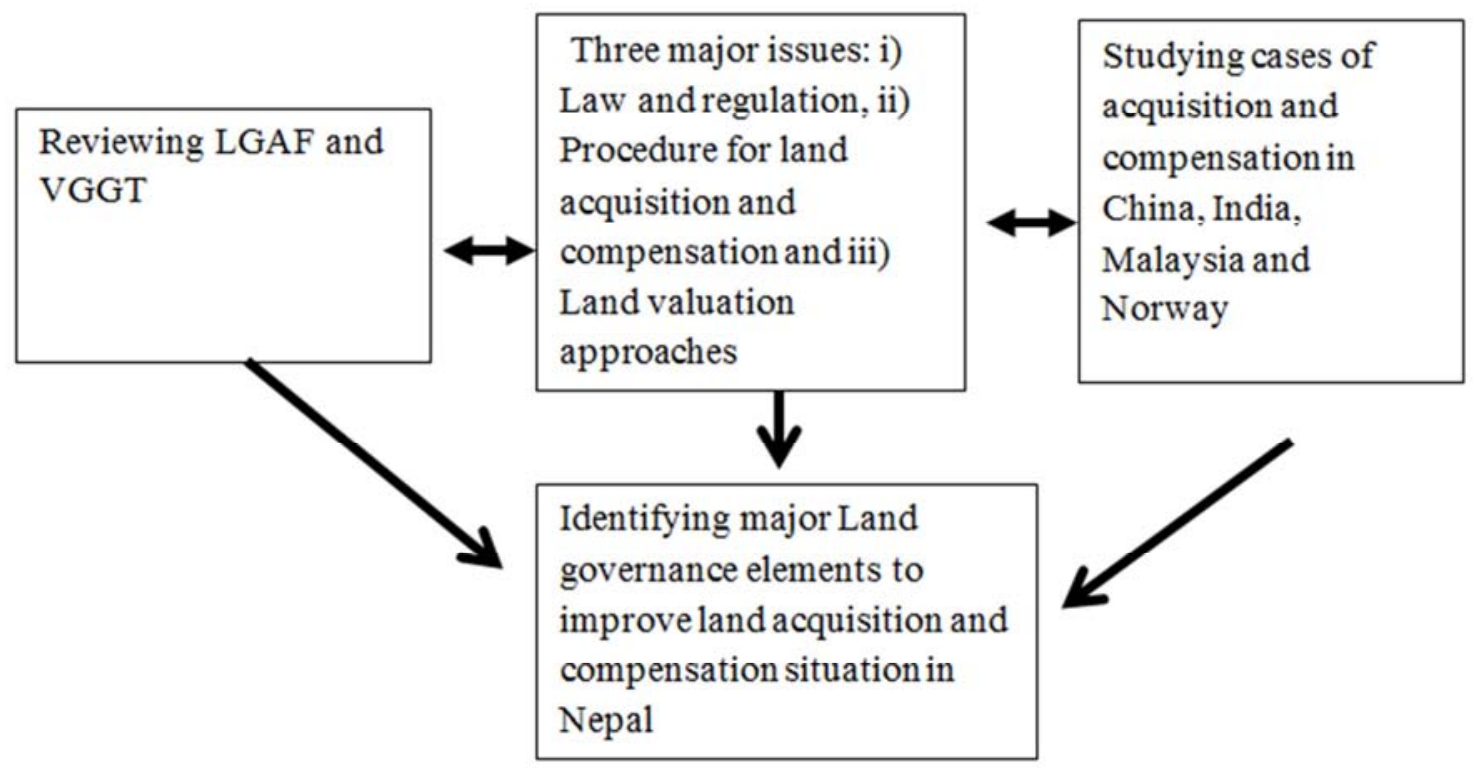

Figure 1. Research Approach.

The types of document used for the case studies are scholarly articles, conference papers, valuation reports, Environmental Impact assessment report etc.

\section{Land Acquisition and Compensation in Infrastructure Development}

This section discusses major land issues such as law and regulation, procedure for land acquisition and compensation and valuation approaches in land acquisition and compensation.

These three issues are the major land issues in land acquisition and compensation as indicated in section 1 forsustainable infrastructure development.

a) Law and regulation

A legal regulation is a written document which shows contractual relationship of rights. Democratic societies rest on freedom of the people and the right to acquire hold and enjoy the property. These are characteristics of natural rights of the people. The property is financial and considered as an economic asset and also has sentimental and emotional value [16]. The right to property is not an absolute and has always been considered as being subject to eminent domain, an inherent right of the state and also an essential part of the state sovereignty [17]. Expropriation considers two essential conditions; private property is to be taken only for public benefit; and just compensation must be paid for the property acquired. Many developed countries such as Germany, Holland and Spain have a regulation or valuation law arranging property valuation. Eminent domain in common law is the inherent power of the state to acquire a citizen's private property with due monetary compensation [18]. Even though a system on property value has been established in many developed countries, administrative problems in developing countries continue. The Lack of legal regulations and standards on determining land values are the main problems. In this context, law, regulations and similar legal arrangements should be made primarily. Land policy, rule of law and land rights are the governance principle considered for this issue as it is an essential condition for economic and social development as indicated by VGGT.

b) Procedure for land acquisition and compensation

Land acquisition by expropriation involves the compulsory taking of land. The compulsory land acquisition is the action and right of the government to take land for public use for public benefit in the countries having private land ownership. The procedure and practices of land acquisition for infrastructure development differs among the countries. There are various ways of acquiring land such as voluntary purchase, land readjustment and compulsory purchase. The exchange of land is known as voluntary purchase [19]. The land readjustment allows land assembly, especially when budgets for compulsory purchase and infrastructure provision are limited [20]. The compulsory purchase is the expropriation of land with use right or ownership right. The idea for the expropriation comes from sovereign's power of eminent domain. This power permits the state to acquire private land for the benefit of the society and is undertaken worldwide [21]. Compulsory purchase is one of the ways in which local and national governments acquire land for development purpose [14]. "If compulsory land acquisition is 
done poorly, it may leave people homeless and landless, with no way of earning a livelihood, without access to necessary resources or community support, and with the feeling that they have suffered a grave injustice. If projects carry out compulsory acquisition satisfactorily, they leave communities and people in equivalent situations while at the same time providing the intended benefits to society" [22].

In many developing countries, compulsory land acquisition is not successful [8]. It is a challenging task that may enhance land conflicts as well as social and economic problems. People are unaware about land acquisition procedure due to lack of transparency and lack of access to information about the projects [23]. Therefore, the infrastructure development projects are not sustainable. The landowner gains the right to receive a monetary payment not less than the loss imposed on him in the public interest but no greater. The reasons behind providing the compensation on land acquisition is to ensure that affected landowner is no worse off and no better off as a result of his eviction [24]. The clear and transparent expropriation procedure, fair compensation, expropriation for public purpose is the governance indicators for this issue.

c) Land valuation approaches for compensation

Land valuation system has attained different level of development in countries around the world. The classical valuation method is used in expropriation all over the world. There are number of professional valuation organizations in developed countries. The most popular are International Valuation Standards Committee (IVSC), The European Group of Valuers' Associations and Appraisers Association of Turkey. These professional organizations have been established to develop and extend international valuation standards, ensure reliability and transparency of land valuation activities, collect professional organizations and facilitate information exchange, etc. [25]. The compensation being paid is not adequate by using the backward type of valuation system such as comparative, income and cost replacement method. This creates insecurity on their land holdings. A standard is defined for the member countries of the World Bank by the International Valuation Standards Committee (IVSC) and this standard defines the general valuation principles. The standard has an expert centered approach and this means the expert will transfer the market value to his/her customer on condition of adhering to the code of ethics. In many European countries, various land valuation systems have been established depending on their purpose but no land valuation system exists in the Croatia. Rapid economic growth in cities with scarce land resources has generated a wave of new thinking on land values and land markets among scholars and policymakers [26]. These dilemmas have led to a new orientation for the land valuation for land acquisition in infrastructure development. There is lack of proper valuation model for providing compensation during land acquisition. Land conflicts resolution, transparent land valuation procedure, uniformly applied and publicly accessible are the principles of governance applied for the issue [LGI10].
Based on the above discussion, rule of law, access to information, public participation, transparent procedure and stakeholder's interaction are the major governance principles that are applicable to land acquisition and compensation for infrastructure development projects.

\section{International Experiences of Land Governance in Land Acquisition and Compensation}

In this section, land acquisition and compensation experiences in China, India, Malaysia and Norway are reviewed to ascertain the gaps discussed in above section in implementing governance principles in land acquisition and compensation. China, India and Malaysia are chosen as main determinants, as they are the neighboring countries of Nepal. Norway is chosen to review their good practices in land governance in acquisition and compensation.

\subsection{Land Acquisition and Compensation in China}

In this section, three major land acquisition and compensation issues are discussed. They are Law and regulations, procedure for land acquisition and compensation and land valuation approaches for compensation.

a) Law and regulations

Land is acquired based on the provisions of the People's Republic of China Land Administration Law and this law does not incorporate the issue of just compensation to the project affected people and has caused high dissatisfaction. The compulsory land acquisition is known as 'Zhengdi' in China. Zhengdi was authorized by the Constitution of the People's Republic of China in 1978 and later amended in 1993 [27]. Chinese Constitution states that ['the] state may, in the public interest, requisition land for its use in accordance with the law." In 1991, the State Council promulgated hydroelectric Power Projects Land Acquisition Compensation and Migrants Resettlement Regulations in 1991. Based on these regulations, improvements and crop compensation for the farmland shall be 3-4 times the average annual production in the past three years prior to acquisition. In China, neither the principle of just terms compensation nor value to the owner is mentioned in the compensation laws. Therefore, it causes dissatisfaction to the land owners on land acquisition. The value of the land should be mentioned to decrease the dissatisfaction of the project affected land owners. Several violations of the rules and regulations during land acquisition and compensation were observed including the lack of provisions to enable residents to continue farming after resettlement and the lack of input regarding the settlement process from the affected families themselves.

b) Procedure for land acquisition and compensation

The land compensation payment is based on 6-10 times its average production value in the past three years prior to acquisition for arable land. The settlement subsidy payment to each person who needs to be resettled is based on 4-6 times the average production value of the land taken in the 
past three years prior to acquisition. However, the maximum payment for each hectare of acquired land shall not be higher than 15 times the average production value in the past three years prior to acquisition. If the land compensation and settlement subsidy payments are insufficient to maintain the affected farmers' original quality of life level, the amount of settlement subsidy payment can be increased pending approval by the relevant authorities. But the total payment for land compensation and settlement subsidy shall not exceed 30 times the average production value of the acquired land in the past three years prior to acquisition. For tenants and persons with unclear property titles, the acquiring authority needs to pay tenants' removal costs. The standards for removal costs and temporary settlement subsidies are to be determined by the relevant people's governments of province, autonomous city, and municipality directly controlled by the Central Government. The concessions procedure is also followed in hydropower development but it is without broader negotiations and agreements. Therefore, Chinese hydro concessions are controversial [28]. Because of lack of access to information and transparency in planning processes, $\mathrm{Nu}$ river project faces obstacles in its development. While dealing with expropriations, there is a weakness in engaging stakeholders and access to information.

c) Land valuation approaches for Land Acquisition

The compulsory acquisition of land is common in practice for infrastructure development. State can acquire the collectively owned land and can change into the state owned land. At present, land in urban and rural areas can be compulsorily acquired for construction purposes. Under the land acquisition law in China, compensation is given to the project affected people. However the heads of compensation are limited and there is no reference to just terms compensation. The valuation is based on sale comparison and market economic principle i.e supply and demand principle. A free market is a system in which the prices for land are set freely by consent between project developers and land owners in which the laws and forces of supply and demand are free from any intervention by a government.

There is provision of law and regulations for land acquisitions and compensations in Infrastructure development in China but criteria for just compensation are not clear and cause dissatisfaction. There is lack of access to information and transparency in planning process in $\mathrm{Nu}$ river project. The sales comparison method is commonly used for land valuation. There is weakness in engaging stakeholder during the development of infrastructure development. The good governance principle such as access to information, public engagement, transparent procedure and stakeholder's interaction is essential for sustainable infrastructure development.

\subsection{Land Acquisition and Compensation in Malaysia}

In this section, three major land acquisition and compensation issues are discussed. They are Law and regulations, procedure for land acquisition and compensation and land valuation approaches for compensation.

a) Law and regulations

Land is acquired in Malaysia under the Land Acquisition Act 1960. The courts have declared that the requirement may be satisfied by expressing adequate compensation in terms of money. The practitioners rely upon the concept of market value that is also provided under the laws of compulsory acquisition. The law requires in any acquisition of land that the State Authority pay adequate compensation. The term adequate compensation is not defined and also market value and adequate compensation are not defined in acquisition laws, neither has it been contended that adequate compensation and market value are the same thing. The market value is the best method of satisfying the requirement that adequate compensation is paid. The logic is sound and implemented well in practice. Therefore, it is the desire of the state to give adequate compensation based only on market evidence, and if each party involved in land acquisition will act in accordance with professional ethics, honesty and integrity, the objective of arriving at adequate compensation will be achieved based on market value [29]. The rule of law is the major land governance indicator in this issue.

b) Procedure for land acquisition and compensation

The compensation based on the market value is considered to be satisfactory [30]. It is also found that there is a feeling that an additional payment, probably a percentage of the value, should be paid to all property owners of project affected area. Eminent domain is subject to two essential conditions: private property is to be taken only for public use and just compensation must be paid for the property taken [31]. Land acquisition is also the tool to assemble land in resolving the land supply problems for infrastructure development. Land assembly through land acquisition is a way out to solve problems with landownership and landowners' reluctance to offer their land for infrastructure development [32]. The power of compulsory purchase supports the land assembly negotiations in order to avoid situations where individual landowners can freeze development by refusing to sell, particularly by trying to hold out for unreasonable purchase price [33].

c) Land valuation approaches for land acquisition

The main issue of land valuation in Malaysia is the quantum of compensation that is perceived by the affected people as inadequate to fulfill adequate compensation according to the spirit of Constitution. The review in the heads of compensation structure is necessary focusing on practices of other countries. Generally in Malaysia, market value is the appropriate basis for compensation for land taken and literature indicates that a solatium or premium should be paid to compensate affected people. Most of the valuers perceived that land acquisition need not necessarily present the best alternative for government to secure land for development. The adequate compensation is the major governance indicator in this issue.

There is provision of land acquisition act in Malaysia and the adequate compensation is based on the market value in Malaysia. An additional payment known as solatium should 
be paid to all property owners of project affected area to satisfy the project affected people. The rule of law, fair compensation and involvement of stakeholders in the process of land acquisition and compensation are the major determinants in the processes.

\subsection{Land Acquisition and Compensation in India}

In this section, three major land acquisition and compensation issues are discussed. They are Law and regulations, procedure for land acquisition and compensation and land valuation approaches for compensation.

a) Law and regulations

The Right to Fair Compensation and Transparency in Land Acquisition, Rehabilitation and Resettlement Act has endorsed for providing compensation to project affected people during infrastructure development projects by the Parliament in September 2013. This act brings transparency in land acquisition and provides generous compensation and rehabilitation of affected people. The main objective of this law is making process of land acquisition fairer, efficient and transparent. Land cannot be vacated until full compensation is provided to the project affected people based on this new legislation. The new law not only substantially enhances compensation to the landowners but also tries to do justice to those dependent on that land by prescribing that each affected household including landless laborers and tenants who were dependent on the acquired land are either provided employment, or given a monthly sum of 2,000 for twenty years, or 500,000 in lump sum [33]. The efficient and transparent process of land acquisition, full compensation to the project affected people is the governance indicators in this issue.

b) Procedure for land acquisition and compensation

The acquisition of land by government and project developers has drawn resistance in many cases due to inadequate compensation and loss of livelihoods of the affected people. Therefore, land acquisition is the most important structural constraint in India for the development of infrastructure. The delays in acquisition of land lead to uncertainty and cost change and affect infrastructure development. The land acquisition process in India is considered as a controversial and debatable. The most land was acquired by government for large irrigation projects, public sector enterprises, and new townships and therefore the use of coercive legal powers carried at least some credibility in the eyes of the public before 1990. In the last two decades, eminent domain has also been carried out for acquisition and for land valuation. Such private enterprises contribute to direct and indirect employment generation but the people's perception of these activities being in 'public interest' is generally negative, and therefore they are less tolerant of being made to leave the area or accept unfair compensation. There has been increasing protest and militancy leading to tension, conflict and violence, besides litigation that increases uncertainty and costs involved in delayed possession of land. In addition to cash compensation, the law provides for new houses for all affected families whose houses have been acquired, provided they have been residing in the affected area for 5 years or more and have been displaced. If project affected people choose not to accept the house they are offered a one-time financial grant instead of the same.

c) Land valuation approaches for land acquisition

The valuation of land is poorly developed as the most important land related decisions and valuations were internal to the government [34]. The compensation would be double the market price for urban areas and two to four times the market value for rural areas for the government projects. The market value is determined by examining the sale transactions of similar land in that area, and as the written value in such sale deeds is much less than the actual market value, provision has been made to give much more than the registered sale value to the affected landowners, so as to ensure fair compensation. The proper valuation of land and compensation for lost assets are very important counteractions to mitigate impoverishment risks for affected persons. If there is a plentiful supply of a land and little or no demand, the price of the land is likely to be low, whereas, if there is little supply and a great deal of demand, the price will be higher. In the land valuation, it is common to assume that the value and potential of a property is fundamentally determined by its location, access to existing infrastructure and its productivity. The principle of comparison underpins all valuation methods but sales comparison is always preferred method of valuation. The degree of similarity or difference between the subject property and the comparable sales is usually established on the following elements of comparison: property rights conveyed, conditions of sale, market conditions, location, physical characteristics, economic characteristics, use (zoning) etc.

India endorsed the right to Fair Compensation and Transparency in Land Acquisition, Rehabilitation and Resettlement Act to address the land acquisition and compensation during infrastructure development. There is lack of broad participation and access to information in making land related decisions in India.

\subsection{Land Acquisition and Compensation in Norway}

This section is discussed in three major land valuation issues in Norway; Law regulations, procedures for land acquisition and compensation and Land valuation approaches for acquisition.

a) Law and Regulations

The Norwegian legal description of compulsory acquisition follows from the Constitution of the Kingdom of Norway. "If the State's needs demands that somebody must leave his movable or immovable property for the public use he should have full compensation from the treasury Norwegian law allows expropriation for public and even for many private purposes" [35]. Appropriate or fair compensation should enable the former owner to buy another property with the same characteristics as the taken one. Thus, the compensation has to include i) the value of the taken property depending on the objective current value of the 
property (= market value) and additional payments because of consequential damages to cover individual losses of the owners. The legal procedure, appropriate compensation etc. are the major indicators in this issue.

b) Procedure for land acquisition and compensation

The public hearings and specific contact with affected right holders must be carried out to manage the land acquisition and compensation and agreement possibilities must have been tried out (the Principle of Negotiation First). Before expropriation starts, the right holder normally should have been contacted three times: in connection with the public hearing of the plan or impact assessment, specific hearing about the acquisition, and during the negotiation effort. The provision of Expropriation is given by a specific formal decision after a weighing of public benefit and private problems and losses (the Principle of Proportionality) and a discussion of other options than acquisition (the Principle of Necessity). Landowner can complain on more of these elements. The expropriation court which main task is to calculate compensations should even checkup. The open discussion is held at local, regional and national level in hydropower development. The hydropower development in Norway is based on broad public participation to ensure that all the interests are recognized and taken into consideration at several stages of the development process [36]. According to
International Energy Agency (IEA) Hydropower Implementing Agreement Annex VIII, comprehensive planning is well considered in Aurland hydropower development project. The public participation is the major land governance indicators in this issue.

c) Land valuation approaches for land acquisition

It is to be noted that most expropriators use a lot of time, effort and human skills and decency to get to a voluntary agreement. Even if the negotiation fails in the first phase the efforts will normally go on until the valuation court has begun the proceedings. Even during the proceedings agreement quite often succeeds. The case is now brought to the Valuation Court. The expropriator has the duty to bring all information needed before the Court. The Court task is to calculate compensations in accordance with the Expropriation Compensation Law. The procedures follow normal court standards with lawyers on both sides. The court's decision (the compensations and the interpretation of standards) can be appealed to higher courts. When all appeal possibilities are ended the expropriator can acquire the property after paying the compensation sum and all procedural costs included. There are no standardized methods for the actual valuation. The Courts can decide what calculations or models to use. Due to this, compensations seem to differ in sometimes unpredictable ways.

Table 1. Summary of Land Governance Issues and Indicators.

\begin{tabular}{|c|c|c|c|c|}
\hline S no & Issues Countries & Law and regulations & Procedure for land acquisition & Land valuation approaches \\
\hline \multirow{3}{*}{1} & \multirow{3}{*}{ China } & \multirow{3}{*}{$\begin{array}{l}\text { Provisions of the People's } \\
\text { Republic of China Land } \\
\text { Administration Law } \\
\text { Does not incorporate the } \\
\text { issue of just compensation. }\end{array}$} & \multirow{4}{*}{$\begin{array}{l}\text { Compensation based on 6-10 times. The settlement } \\
\text { subsidy payment based on 4-6 times and maximum } \\
\text { payment for each hectare of acquired land shall not be } \\
\text { higher than } 15 \text { times the average production value. } \\
\text { Public participation, access to information and transparent } \\
\text { procedure is not broadly involved } \\
\text { An additional payment, probably a percentage of the } \\
\text { value, should be paid to all property owners. Public } \\
\text { participation, access to information and transparent } \\
\text { procedure is not broadly involved. }\end{array}$} & $\begin{array}{l}\text { Compulsory acquisition of } \\
\text { land is common in practice }\end{array}$ \\
\hline & & & & \\
\hline & & & & $\begin{array}{l}\text { and market economic } \\
\text { principle. }\end{array}$ \\
\hline 2 & Malaysia & Land Acquisition Act 1960 & & $\begin{array}{l}\text { The market value is the } \\
\text { appropriate basis for } \\
\text { compensation for land taken }\end{array}$ \\
\hline 3 & India & $\begin{array}{l}\text { Right to Fair Compensation } \\
\text { and Transparency in a Land } \\
\text { Acquisition, Rehabilitation } \\
\text { and Resettlement Act. }\end{array}$ & $\begin{array}{l}\text { Drawn resistance due to inadequate compensation and } \\
\text { loss of livelihoods of the affected people. } \\
\text { Public participation, access to information and transparent } \\
\text { procedure is not broadly involved }\end{array}$ & $\begin{array}{l}\text { Market value is determined } \\
\text { by examining the sale } \\
\text { transactions and sales } \\
\text { comparison is more } \\
\text { preferred. }\end{array}$ \\
\hline
\end{tabular}

The land valuation issues such as law regulations, procedure for land acquisition and land valuation approaches from governance perspective are very important for infrastructure development. Public participation, access to information and transparent procedure is not broadly involved in the land valuation and acquisition process of infrastructure development in China, Malaysia and India. Therefore, the projects are not successful in developing countries. It is found that different countries have different practices in planning and land acquisition for infrastructure development depending on their willingness and capability to consider the land valuation issues in infrastructure development plan. The benefits of power output and project itself are shared to affected people and stakeholders are involved in the development process in Norway. In China, India, Malaysia and Nepal, mostly land is expropriated without comprehensive planning and broader participation of stakeholders. Involvement of various stakeholders in decision making and implementation of land valuation system is not clear. But to achieve sustainable land valuation system in 
infrastructure development, involvement of various stakeholders without feeling a sense of ownership is insufficient which can creates barrier in transparency, participation, access to information and accountability. The overall gaps identified from previous sections as reviewed are the implementation aspect of land valuation system in reference to Good Governance principles such as rule of law, participation, and access to information, transparent procedure and stakeholder's interaction. The summary of major land governance issues and indicators in land valuation, acquisition and compensation are provided in Table 1.

\section{Land Acquisition and Compensation in Nepal}

This section firstly reviews the current situation, practices and processes of land valuation, acquisition and compensation for infrastructure development in Nepal. Secondly, it analyzes implications of key governance determinants in infrastructure development projects.

a) Law and regulations

Regarding legal protection for ascertaining tenure security, the right to own, acquires, dispose and sell the real property as a fundamental right is ensured by [37]. It ensures protection from requisition acquires or creates any encumbrances without proper compensation and ensures equity in terms of religion, gender, ethnicity etc. to own land. There is lack of integrated act or rule and clear guidelines for Land valuation. There are various act and regulation for land valuation which creates complexity during land valuation. Almost valuation purpose is for legalization. The Legal provision is not sufficient for scientific valuation of land. Involvement of different organizations in land valuation process in Nepal has raised development of controversial land values for a given piece of land [38]. The Immovable Property Acquisition Act 2013 (1956 AD) authorizes the government to acquire immovable property, which is essentially land and permanent structure attached to land, only for public benefit. The Act has a provision of appointing a mediator to fix the rate of compensation. The act no.7 entitled about compensation according to this point, in case any property is requisitioned pursuant to this act, the government of Nepal shall give compensation and the valuation of such compensation shall be calculated as per the principle prescribed as following methods:

(a) In case the amount of compensation is fixed in an agreement, if any, such agreement prevails.

(b) In the absence of agreement, the Government of Nepal shall appoint any judge either sitting or retired as an arbitrator and the compensation shall be given as per the award of the arbitrator.

According to land acquisition act 2034 BS (1977 AD), land is valuated for the purpose of providing compensation during the land acquisition by the government for conducting various development activities. It is based on the current land value, valuation of land revenue office, negotiation with local public. The following committee members decision the valuation of land for compensation:

a Chief District Officer

b Land Administrator or Chief of the Land Revenue Office

c The Project-in-chief, if the land has been acquired for a project, and if it has been acquired for any other purpose, an officer designated by the Chief District Officer,

d A representative of the District Development Committee.

b) Procedure for Land Acquisition and Compensation

Mostly, land is expropriated for infrastructure development. In $144 \mathrm{Mw}$ Kali Gandaki 'A' hydropower project, Nepal Electricity Authority (NEA) acquired about 53.7 hectares of land and 57 houses for the access road. Similarly, 148.62 hectares land was acquired of which 94.2 hectares was private and guthi land for the main project features such as dam, powerhouse and site offices [39]. An Acquisition compensation and rehabilitation plan (ACRP) is prepared as a project document following the process established in the Land Acquisition Act of Nepal. But institutional conditions like differentiating of affected people, low and unfair compensation, exclusion of directly affected families in compensatory procedures and lack of strong consultation processes enhances additional gaps that results instability amongst those affected by the dam intervention. Unless compensatory procedures are nicely laid out and implementation of plans is made transparent, infrastructure projects are not sustainable in a developing country like Nepal with its limited land resources and intricacies of power within social relations [40]. Arun III hydroelectric project in Nepal was cancelled by World Bank since it has not focused on policies related with resettlement and indigenous people and their participation in its stages of development [41].

c) Land valuation approaches for land acquisition

There is no official land valuation system in Nepal except ad hoc land valuation for compensation during land expropriation [6]. The district administration office fixes the land value while determining compensation of expropriated land. The valuation process is often incredibly subjective, with no overarching standards, and the process by which payments are determined is too often in the hands of project developers or government agencies with an incentive to have smaller payments [42].

\section{Results}

The constitution of Nepal ensures the right to own, acquires, dispose and sell the property. It ensures that the land acquisition could not carry out without proper compensation and ensures equity in terms of religion, gender, ethnicity etc. to own land. As reviewed from Kali Gandaki 'A' hydropower project and Arun III hydroelectric project in Nepal, the major land governance indicators such as rule of law, participation (stakeholder's interaction), access 
to information, transparency should be followed in Nepalese infrastructure development to improve the situation in Nepal. An ad hoc committee consisting of Chief District Officer, Land Administrator or Chief of the Land Revenue Office, The Project-in-chief, if the land has been acquired for a project, and if it has been acquired for any other purpose, an officer designated by the Chief District Officer, A representative of the District Development Committee land valuation system exists for land acquisition and compensation in Nepal. It is necessary to lay out the compensatory procedures nicely and implementation of plans should be transparent for sustainable infrastructure projects in Nepal. The projects were cancelled due to lack of their participation in stage of infrastructure development. The valuation process in land acquisition is often incredibly subjective with no standards for land acquisition and compensation.

\section{Discussion}

Land acquisition involves the compulsory taking of land, often against the will of the landowners. The law in Malaysia requires the state to pay compensation adequately; however, adequate compensation is not defined in the statute which causes dissatisfaction to project affected people. There is a need to review the heads of compensation structures by incorporating payment of solatium or premium as over and above total compensation. The rule of law, Public participation, access to information, transparent procedure, stakeholders interaction are the major governance principles as indicated by VGGT and LGAF and international experiences from four countries and may be implemented at different points to monitor progress in land governance, It can also be used comparatively to identify good practices that can determine bench works for other countries such as Nepal. The study shows that land governance principle are followed in Norway with comprehensive planning and it makes the infrastructure developing more sustainable comparing to China, India and Malaysian infrastructure development. An ad hoc committee is formed for land valuation system in Nepal. The review on infrastructure development in Nepal indicates that good governance principle is not adequately followed in land acquisition and compensation processes and should be followed to improve the situation of land governance in acquisition and compensation.

\section{Conclusion}

The practice in compulsory purchase and compensation is quite different in different countries due to social, economic and political condition of the country. The study concludes that different countries have different legal instruments, procedure for land acquisition and land valuation approaches depending upon social, political and economic condition of the country. The country implementing public participation, broader agreements and negotiations in land acquisition got successful in infrastructure development while others not implementing these issues do not get successful in its development. Therefore, the overall gap identified is the implementation of land governance principles such as public participation, access to information and transparent procedure in land valuation, acquisition and compensation processes. The paper concludes with key lessons learnt in the context of land governance in land valuation and acquisition and compensation process. The good governance principle such as public participation, access to information, transparent procedure and adequate compensation should be followed for developing countries like Nepal for sustainable infrastructure development that can be evidenced by the infrastructure development in Norway.

\section{References}

[1] Burns, T. (2007). Land administration reform: indicators of success and future challenges. Agriculture and Rural Development Discussion Paper, 37.

[2] Cash, D. W., Adger, W. N., Berkes, F., Garden, P., Lebel, L., Olsson, P. (2006). Scale and cross-scale dynamics: Governance and information in a multilevel world. Ecology and Society, 11 (2).

[3] Belej, M., \& Walacik, M. (2008). Land Acquisition for Public Purpose in Poland on Example of Public Roads Construction. Retrieved from

http://www.fig.net/pub/fig2008/papers/ts04b/ts04b_03_belej_ walacik_2849.pdf

[4] Dutta, B. K, (2015) Web based land valuation system in infrastructure planning in India: An approach, proceeding Real Corp, Tagungsband.

[5] Williamson, I., \& Grant, D. M. (2002). United Nations-FIG Bathurst Declaration on Land Administration for Sustainable Development: Development and Impact. Paper presented at the FIG XXII International Congress.

[6] Tuladhar, A. M. (2004) Parcel - based geo - information system: concepts and guidelines., ITC, Enschede.

[7] Nandalal, H. K. (2007). Importance of Public Participation in Project Implementation: Upper Kotmale Hydropower Project in Srilanka. International conference on Small HydropowerHydro Srilanka, 22-24 October 2007.

[8] Ogunlana, S., Yotsinsak, T., \& Yisa, S. (2001) An Assessment of People's Satisfaction with the Public Hearing on the Yadana Natural Gas Pipeline Project Environmental Monitoring and assessment, 72 (2), 2001, 207-225.

[9] Atahar, S. (2013). Development Project, Land Acquisition and Resettlement in Bangladesh; A Quest for Well Formulated National Resettlement and Rehabilitation Policy, International Journal of Humanities and Social Science Vol. 3 No. 7; April.

[10] Enemark, S., R. McLaren \& V. d. M. Paul (2009) Land Governance in support of the Millennium Development Goals: A New Agenda for Land Professionals. FIG / World Bank.

[11] Graham, J. (2003). Principles for good governance in the $21 \mathrm{st}$ century, Policy brief, 15. 
[12] FAO, \& UN-HABITAT. (2009). Towards Improved Land Governance. In David Palmer, Szilard Fricska \& B. Wehrmann (Eds.).

[13] Agere, S. (2000). Promoting Good Governence; principles, Practices, and Perspectives, London: Common wealth Secretariat, 2000.

[14] Viitanen, K., \& Kakulu, I. (2009) Global Concerns in Compulsory Purchase and Compensation Processes.

[15] Rai, K. (2004). Hydropower development in Nepal: Local Responses to Technology and Formal Insitutions. Conference on International Agricultural Research for development, 5-7 October 2004.

[16] Jain, M. P. \& Xavier G. (1996). Compulsory Acquisition in Malaysia, 2 MLJ xxix.

[17] Ghosh, A. (1973). The Land Acquisition Act 1894-Law of Compulsory Acquisition and Compensation, Sixth Edition, Eastern Law House, 1973.

[18] Candas, E., \& Yomralioglu, T. (2014, 16-21 June 2014). The Land Valuation Issues In Turkey. Paper presented at the FIG Congress 2014.

[19] Seppanen, H. (2004). Land Acquisition and Compulsory Means - Cooperation Creates Satisfaction. from http://www.fig.net/pub/athens/papers/ts24/TS24_4_Seppanen.p df, 2004

[20] Home, R. (2007). Transposing legal instruments for common property rights: The examples of condominium and land readjustment. Paper presented at the International Conference, Sustainable Urban Areas. Retrieved from http://www.enhr2007rotterdam.nl/documents/W09_abstracts.p df

[21] Kitay, M. G. (Ed.) (1985). Land Acquisition in Developing Countries: Policies and Procedures of the Public Sector: With Surveys and Case Studies from Korea, India, Thailand, and Ecuador. 131 Clarendon Street, Boston, MA 02116: Oelgeochlagcr, Gunn \& Hain in association with the Lincoln Institute of Land Policy, 1985.

[22] FAO (2008).' Compulsory land acquisition and Compensation. FAO Land Tenure Studies No. 10, RomeConference, FIG, Washington DC.

[23] Oluwamotemi, D. K. (2014). Land Acquisition, Compensation And Resettlement In Developing Economies: Nigeria As A Case Study. TS IE - Environment and Energy: Policy and Practice Retrieved July 10, from www.fig.net/pub/fig2010/papers/ts06e\%5Cts06e_oluwamote mi_3616.pdf

[24] Brown, D. (1996). Land Acquisition: An examination of the principles of law governing the compulsory acquisition or resumption of land in Australia and New Zealand. 4th edition, Butterworths.

[25] Yomralığlu, T., Nişancı, R., Çete, M., Candaş, E. (2011). Real Estate Valuation in Turkey and the World, Workshop on Sustainable Land Management in Turkey, Okan University.

[26] Lam, A (1995). Land Value Issues in Taiwan, Korea, and Japan, Land line: Vol 7, No 6, Retrieved from July 25, 2015 from http://www.lincolninst.edu/pubs/534 Land-Value-Issuesin-Taiwan--Korea--and-Japan.
[27] Chan, N (2003). Land Acquisition Compensation in China Problems \& Answers. International Real Estate Review, 136152.

[28] Ryder, G (2008). Analysis: Chinese hydro concessions generate controversy in Cambodia,. Retrieved February 15, 2015, from http://www.probeinternational.org/mekong-utilitywatch/analysis-chinese-hydro-concessions-generatecontroversy-cambodia

[29] Khublal, N. (1994). Compulsory Land Acquisition- Singapore and Malaysia, 2nd Edition, Butterworth Asia.

[30] Dundas, I. H. M \& Evans W. M. (2001). Review of Compulsory Purchase and Compensation, Scottish Executive Central Research Unit.

[31] Alias, A. \& Daud, M. (2006). Payment of adequate compensation for land acquisition in Malaysia.

[32] Omar \& Ismail (2005). Discrepancies in Defining Adequate Compensation in Land Acquisition: A Case Study in Malaysia, 1st REER Conference and General Meeting, UTM City Campus, 6-7 September.

[33] GOI (2013). Right to Fair Compensation and Transparency in a Land Acquisition, Rehabilitation and Resettlement Act.

[34] Morris, S., \& Pandey (2007). A. Towards Reform of Land Acquisition Framework in India.

[35] Steiinsholt, H. (2010). Some Aspects of Norwegian Expropriation - Input to Comparative Studyof Chosen Expropriation Issues: Germany, Norway and Poland Håvard, accessed on December 9, 2015, http://www.fig.net/resources/proceedings/fig_proceedings/fig2 010/papers/ts03f/ts03f_steinsholt_4307.pdf

[36] NEP/DDP (2001). Response to the final report: Norwegian Ministry of Foreign Affairs,, Retrieved December 16, 2015, from

http://www.unep.org/dams/documents/default.asp?documentid $=505$.

[37] GoN (2015). Consitution of Nepal.

[38] Subedi, G., \& Chhatkuli, R. (2010). Land Policy Issues in Nepalese Context. Nepalese Journal on Geoinformatics no. 9, 30 .

[39] KGEMU, \& Inc, M. K. I. (2002). Impoverishment Risks Monitoring and Management in Kali Gandaki 'A' Hydroelectric Project, 2002, Beltari, Syangja, Nepal.

[40] Rai, K. (2004). Hydropower development in Nepal: Local Responses to Technology and Formal Insitutions. Conference on International Agricultural Research for development, 5-7 October 2004.

[41] Udall, L. (1995). Arun III Hydroelectric Project In Nepal: Another World Bank Debacle? 1. Retrieved December 07, 2015, from http://www.hartfordhwp.com/archives/52/054.html

[42] Coca, N., \& Paudel, S (2012). Public Interest and Compensation: Resource Development in Nepal. 